\title{
Effect of Applied Potential and Sulfate Reducing Bacteria on Corrosion Behavior of X80 Steel in Dagang Soil Simulated Solution
}

\author{
Xiaoqing Sun, Fei Xie*, Dan Wang, Ji Qi
}

Key Laboratory of Oil \& Gas Storage and Transportation, College of Petroleum Engineering, Liaoning Shihua University, Fushun Liaoning, 113001, China.

"E-mail: xiefei0413@163.com

doi: $10.20964 / 2020.06 .35$

Received: 3 February 2020 / Accepted: 31 March 2020 / Published: 10 May 2020

The corrosion behavior of X80 steel in Dagang soil simulated solution was verified by potentiostatic immersion test and AC impedance test, and the corrosion morphology of metal surface under different applied potential in bacterial solution and sterile solution was observed by scanning electron microscope (SEM).The results showed that the existence of sulfate reducing bacteria (SRB) can increase the corrosion trend of metals. In the simulated solution, the corrosion of samples became more and more serious with the increase of soaking days. With the negative shift of applied potential, the electrochemical corrosion rate of X80 pipeline steel was lower than that under self-corrosion potential.

Keywords: applied potential, SRB, X80 pipeline steel, AC impedance test

\section{$\underline{\text { FULL TEXT }}$}

(C) 2020 The Authors. Published by ESG (www.electrochemsci.org). This article is an open access article distributed under the terms and conditions of the Creative Commons Attribution license (http://creativecommons.org/licenses/by/4.0/). 